\title{
In vitro bioactivity of gonadotrophin surge attenuating factor is not affected by an antibody to human inhibin
}

\author{
A. H. Balen ${ }^{1,2 *}$, J. Er ${ }^{2}$, B. Rafferty ${ }^{2}$ and M. Rose ${ }^{2}$ \\ ${ }^{1}$ Department of Endocrinology, Cobbold Laboratories, The Middlesex Hospital, London W1N 8AA, UK; \\ and ${ }^{2}$ Department of Endocrinology, National Institute for Biological Standards and Control, Blanche Lane, \\ South Mimms, Hertfordshire EN6 3QG, UK
}

\begin{abstract}
The effect of anti-inhibin antibodies on gonadotrophin surge attenuating/inhibiting factor (GnSAF/GnSIF) and its effect on gonadotrophin secretion in a pituitary cell bioassay were determined by culturing rat pituitary cells in a serum-free medium to which inhibin and a partially purified preparation of gonadotrophin surge inhibiting factor (GnSIF) were added. The samples were treated with an anti-inhibin antiserum and basal and GnRH-stimulated FSH and LH secretion were measured by radioimmunoassay of the culture supernatant. Inhibin had a dose-dependent inhibitory effect on both basal and GnRH-stimulated FSH secretion and also on GnRH-stimulated LH secretion. Anti-inhibin antibody blocked the inhibition of FSH secretion, except at the highest two doses of human inhibin (1.25 ng $\left.\mathrm{ml}^{-1}, P=0.04 ; 2.5 \mathrm{ng} \mathrm{ml}^{-1}, P=0.0004\right)$. The GnSIF preparation inhibited basal and GnRH-stimulated FSH and GnRH-stimulated LH secretion and was not affected by the anti-inhibin antibody. The novel hormone, GnSIF, is different from inhibin.
\end{abstract}

\section{Introduction}

Ovarian peptide hormones have important effects on pituitary gonadotrophin secretion. Inhibin has been shown to have effects, at different concentrations and in different conditions, on basal secretion of FSH and on both GnRH-stimulated FSH and LH secretion (Burger, 1992). A number of groups have proposed the existence of an inhibitory factor, different from inhibin, that is produced by ovarian follicles and suppresses GnRH-stimulated LH, and possibly also FSH, secretion. This factor has been named gonadotrophin surge inhibiting (Sopelak and Hodgen, 1984) or attenuating (Messinis and Templeton, 1989) factor (GnSIF/GnSAF).

A $37 \mathrm{kDa}$ monomeric polypeptide with GnSIF bioactivity, purified from a rat Sertoli cell culture was found to inhibit both GnRH-stimulated LH and basal FSH secretion (Tio et al., 1994). Other groups are attempting to purify GnSAF from pig (Danforth et al., 1987; Danforth and Cheng, 1993) and human (Fowler et al., 1990) follicular fluid. The hypothesis is that GnSAF antagonizes the priming of the pituitary gland by $\mathrm{GnRH}$ and raises its threshold to the action of GnRH, preventing a premature LH surge. The surge may then occur when high serum oestradiol concentrations increase the sensitivity of the pituitary to $\mathrm{GnRH}$, so overriding the inhibitory factor. If secretion of the putative GnSAF/GnSIF is deficient, hypersecretion of LH might result, as seen in women with the polycystic ovary syndrome (PCOS) (Balen and Jacobs, 1991).

The aim of this study was to test the hypothesis that inhibin and GnSAF are different by examining the differential effects of

*Present address: Nuffield Department of Obstetrics and Gynaecology. John Radcliffe Hospital, Headington, Oxford OX3 9DU, UK.

Received 17 January 1995. inhibin and a highly purified sample of pig follicular fluid, which contained only GnSAF/GnSIF bioactivity (Danforth and Cheng, 1993), and to observe the effect of anti-inhibin antibodies on both of these activities.

\section{Materials and Methods}

The methodology for the pituitary cell bioassay was described by Balen et al. (1995). Anterior pituitary glands were obtained from adult female $(200-250 \mathrm{~g})$ Wistar rats. The animals were killed by $\mathrm{CO}_{2}$ anaesthesia and asphyxiation and, after removal of the pituitary gland, the posterior lobe was dissected free and discarded. The anterior lobes were trypsinized in a solution containing $0.5 \%(\mathrm{w} / \mathrm{v})$ trypsin (Sigma, Poole) and $0.1 \%(\mathrm{w} / \mathrm{v})$ DNase (Sigma) and the pituitary cells were then mechanically dispersed using a $5 \mathrm{ml}$ plastic pipette. The number of dead cells was assessed by Trypan blue exclusion and the preparation was used only if the cell viability was greater than $95 \%$.

The suspension of cells was dispensed into 24-well culture plates (Falcon 3047 plates, Becton Dickinson, NJ) in a final concentration of $4 \times 10^{5} \mathrm{cells} \mathrm{ml}^{-1}$ per well. A serum-free medium was used consisting of Dulbecco's modified essential medium/Ham's F-12 medium (DME/F-12, Sigma) plus a combination of $10 \mathrm{mg}$ insulin $\mathrm{ml}^{-1}$ (Sigma) and $10 \mathrm{mg}$ transferrin $\mathrm{ml}^{-1}$ (Sigma). The medium was supplemented with $0.1 \%(\mathrm{w} / \mathrm{v})$ albumin, $1.2 \mathrm{~g}$ sodium bicarbonate $1^{-1}, 10^{5}$ units $1^{-1}$ (100 $\mathrm{mg} \mathrm{l}^{-1}$ penicillin, $100 \mathrm{mg} \mathrm{l}^{-1}$ streptomycin and $2 \mathrm{mg}$ amphotericin $\mathrm{I}^{-1}$ ) (Sigma).

The pituitary cells were incubated at $37^{\circ} \mathrm{C}$ in an atmosphere of $100 \%$ humidity and $5 \% \mathrm{CO}_{2}$. The culture medium was buffered with bicarbonate to maintain a $\mathrm{pH}$ of between 7.2 and 
7.6. The cells were incubated for $24 \mathrm{~h}$, after which samples were added for $48 \mathrm{~h}$ (basal culture) and then $10^{-8} \mathrm{~mol} \mathrm{GnRH}$ $1^{-1}$ was added for $4 \mathrm{~h}$. Samples were added randomly to quadruplicate wells. The $48 \mathrm{~h}$ basal culture was used for measurement of FSH secretion and the effects of FSHinhibitory factors, as negligible amounts of $\mathrm{LH}$ are secreted in the absence of GnRH (Balen et al., 1995). The $4 \mathrm{~h} \mathrm{GnRH}$ stimulation was used for assay of FSH and LH secretion and the effects of FSH- and LH-inhibitory factors. The supernatants were frozen immediately at $-20^{\circ} \mathrm{C}$ and stored until the gonadotrophin concentrations were measured.

\section{Radioimmunoassay of rat gonadotrophins}

Materials for the radioimmunoassay of rat LH and FSH were kindly supplied by the National Hormone and Pituitary Program, National Institute of Diabetes and Digestive and Kidney Diseases (NIDDK), Baltimore. The reference preparations were NIDDK-rFSH-RP-2 and NIDDK-rLH-RP-3. The sensitivity of the FSH assay was $3.0 \mathrm{ng} \mathrm{ml}^{-1}$ and the sensitivity of the $\mathrm{LH}$ assay was $0.8 \mathrm{ng} \mathrm{mi}^{-1}$. Intra- and interassay coefficients of variation were calculated using internal standard preparations as controls; they were, respectively, $8.7 \%$ and $7.9 \%$ for FSH and $6.9 \%$ and $8.8 \%$ for $\mathrm{LH}$.

\section{Inhibin dose-response}

Two different preparations of inhibin (pig and human) were used because the anti-inhibin antibody was raised against human inhibin and the preparation of GnSIF was purified from pig follicular fluid. The pig preparation was the First International Standard for Porcine Inhibin (Code 86/690) (Gaines Das et al., 1992) in doses of 0.2, 2.0, 6.25, 12.5, 20, 25, 50,100 and $200 \mathrm{iu} \mathrm{ml}^{-1}$. The second preparation was recombinantly derived $32 \mathrm{kDa}$ human inhibin $\mathrm{A}$, which was an NIBSC ampouled preparation, with a nominal content of $5 \mu \mathrm{g}$ per ampoule. In the assay system used, $1 \mu \mathrm{g}$ had a nominal activity equivalent to 40000 units of pig inhibin (86/690) and so doses of $0.15625,0.3125,0.625,1.25,2.5$ and $5 \mathrm{ng} \mathrm{ml}^{-1}$ were given. This conversion factor was used in all of the experiments in this study, pending the definitive International Standard unit for human inhibin.

\section{Inhibin immunoprecipitation with ovine anti-inhibin antibody}

Immunoprecipitation experiments were performed using ovine anti-human I-23 alpha inhibin antibody (Y33), kindly provided by A. McNeilly (Medical Research Council Reproductive Biology Unit, Edinburgh). Non-immunized normal sheep serum (NSS) was also provided as a control. Immunoprecipitation was carried out using Protein-G sepharose (Sigma). The anti-inhibin antibody and the normal sheep serum were incubated with the Protein $-G$ sepharose in a $1: 1$ ratio (sample (ml):Protein-G sepharose (mg)). The incubation was performed overnight at $4^{\circ} \mathrm{C}$. After washing with buffered medium (three times), the Protein- $G$ sepharose-anti-inhibin antibody complex and Protein-G sepharose-NSS were incubated with blank medium, human follicular fluid, pig inhibin (50 iu $\mathrm{ml}^{-1}$ ) and recombinant human inhibin at four concen- trations $\left(0.3125,0.625,1.25\right.$ and $\left.2.5 \mathrm{ng} \mathrm{ml}^{-1}\right)$. The absorbed inhibin was removed by pelleting the Protein- $G$ sepharoseanti-inhibin antibody complex by centrifugation $(400 \mathrm{~g}$, $20 \mathrm{~min}$ ).

A highly purified form of GnSIF was kindly provided by D. Danforth (Ohio State University). The GnSIF preparation was derived from pig follicular fluid ( $\mathrm{pFF}$ ) via a number of purification steps including charcoal extraction, heparin-sepharose, Q-sepharose, Mono-S, hydroxylapatite and gel permeation chromatography (Danforth and Cheng, 1993). This preparation of GnSIF gives two protein bands on electrophoresis (Danforth and Cheng, 1993), of which only one has GnSIF bioactivity, a molecular mass of about $71 \mathrm{kDa}$ and a novel amino-terminal sequence (D. R. Danforth, personal communication). The GnSIF preparation was added at doses of 2,4 and $8 \mu \mathrm{g} \mathrm{ml}^{-1}$. As the GnSIF had been purified from pig follicular fluid, pig inhibin (50 iu $\mathrm{ml}^{-1}$ ) was used as an additional control in these experiments.

\section{Statistical analysis}

The mean ( \pm SEM) was calculated for each group of replicated samples. The $\mathrm{ED}_{50}$ value was calculated as the dose at which $50 \%$ inhibition was achieved compared with the controls. One-way analysis of variance was used to compare the differences between the means of the samples and a value of $P<0.05$ was considered to be significant. The analyses were performed using the Minitab statistical package (Minitab Inc., New York).

\section{Results}

Pig inhibin (1st I.S., NIBSC 86/690) had a dose-dependent inhibitory effect on both basal and GnRH-stimulated FSH secretion and a less marked effect on GnRH-stimulated LH secretion (Fig. 1). At least $6.25 \mathrm{iu} \mathrm{ml}^{-1}$ and $12.5 \mathrm{iu} \mathrm{ml}-1$, respectively, were required to obtain inhibition of basal and GnRH-stimulated FSH secretion. The $\mathrm{ED}_{50}$ value for basal FSH was $11 \mathrm{iu}$ inhibin $\mathrm{ml}^{-1}$ and, for GnRH-stimulated FSH, 17 iu $\mathrm{ml}^{-1}$. The $\mathrm{ED}_{50}$ value was not achieved for either basal or GnRH-stimulated $\mathrm{LH}$ secretion, although the $\mathrm{ED}_{25}$ value for the latter was $40 \mathrm{iu} \mathrm{ml} \mathrm{ml}^{-1}$. There was a similar effect of recombinant $32 \mathrm{kDa}$ human inhibin $\mathrm{A}$ on $\mathrm{FSH}$ secretion, but its effect on LH secretion was less pronounced (Fig. 2). The $E_{50}$ value for basal FSH was $0.8 \mathrm{ng}$ inhibin $\mathrm{ml}^{-1}$ and, for GnRHstimulated FSH, $3.9 \mathrm{ng} \mathrm{ml}^{-1}$. The $\mathrm{ED}_{50}$ value was again not achieved for either basal or GnRH-stimulated LH secretion, and the $\mathrm{ED}_{25}$ value for the latter was $4.5 \mathrm{ng} \mathrm{ml}^{-1}$.

Two separate experiments were performed using the preparation of GnSIF, with similar results. The data from one of these experiments are presented here. There was significant inhibition of basal FSH secretion by recombinantly derived human $\left(0.313,0.625,1.25\right.$ and $\left.2.5 \mathrm{ng} \mathrm{ml}^{-1}\right)$ and purified pig (50 iu $\mathrm{ml}^{-1}$ ) inhibin (Fig. 3). The four doses of human inhibin inhibited basal FSH secretion by $61.6 \%, 75.4 \%, 75.7 \%$ and to below the sensitivity of the radioimmunoassay, respectively, and the single dose of pig inhibin achieved $75 \%$ inhibition. Anti-inhibin antibody completely blocked the inhibition of FSH secretion, except at the highest two doses of human inhibin 

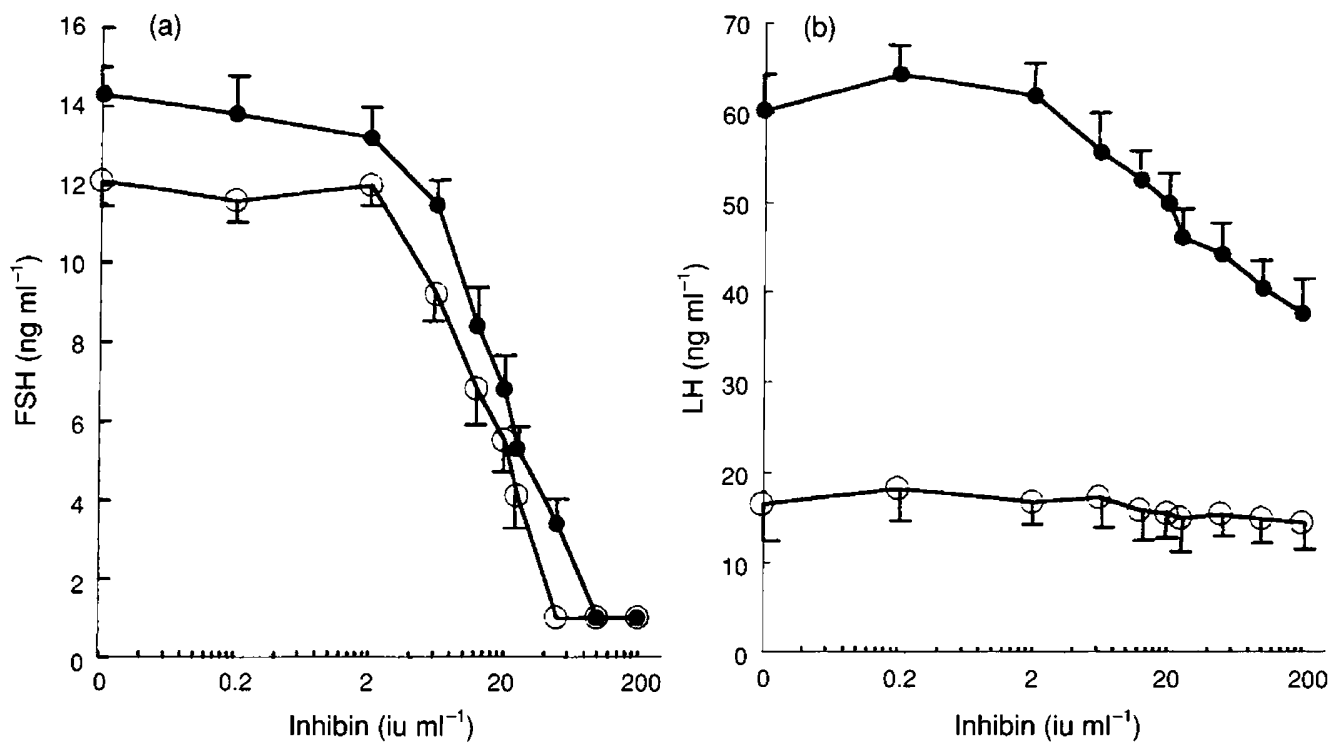

Fig. 1. Dose-response curve of cultured rat pituitary cells to pig inhibin, illustrating the effects of inhibin on (a)

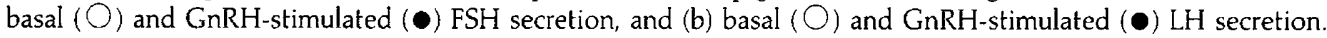
Basal secretion was measured over $48 \mathrm{~h}$ followed by $4 \mathrm{~h}$ stimulation with $10^{-8} \mathrm{~mol} \mathrm{GnRH} \mathrm{l}^{-1}$. ED $\mathrm{ED}_{50}$ value for basal FSH was 11 iu inhibin $\mathrm{ml}^{-1}$, for $\mathrm{GnRH}$-stimulated FSH, $17 \mathrm{iu} \mathrm{ml}^{-1}$. The $\mathrm{ED}_{50}$ value was not achieved for either basal or GnRH-stimulated $\mathrm{LH}$ secretion, although the $\mathrm{ED}_{25}$ value for the latter was $40 \mathrm{iu} \mathrm{ml}^{-1}$.
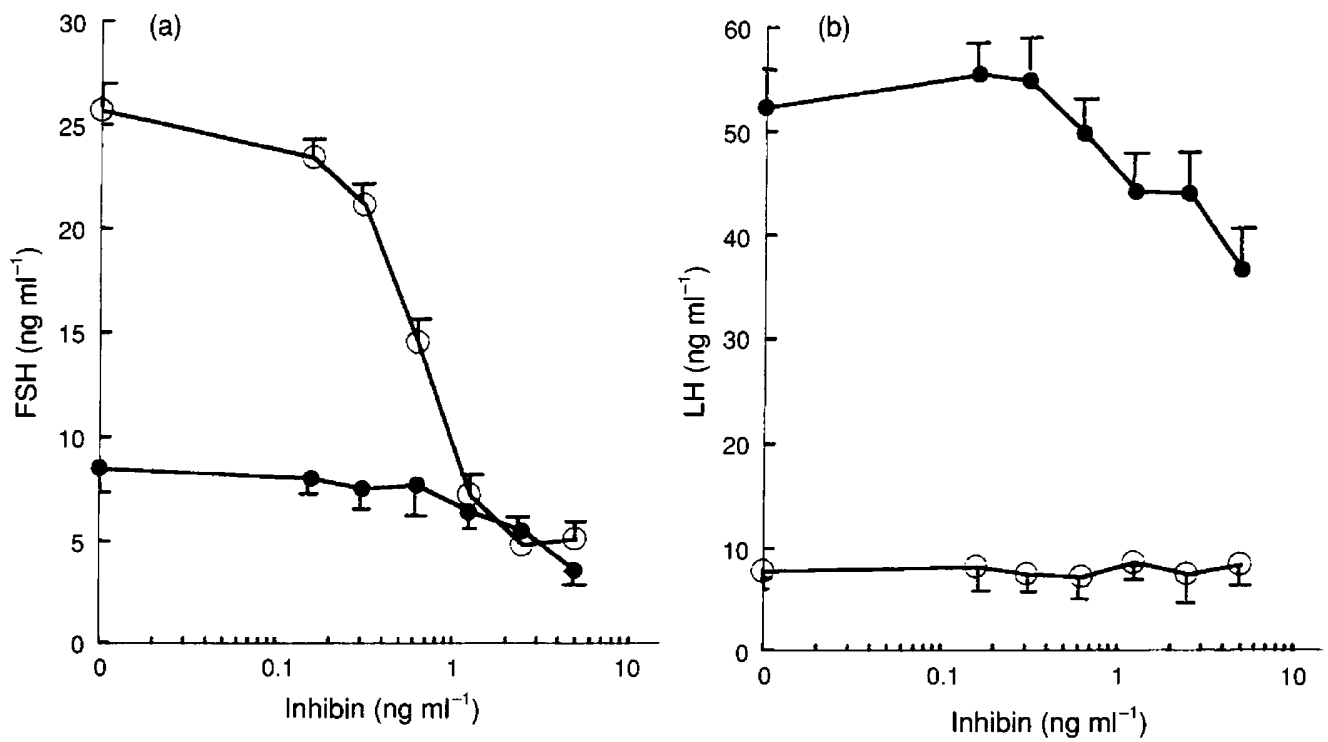

Fig. 2. Dose-response curve of cultured rat pituitary cells to recombinant human inhibin, illustrating the effects of inhibin on (a) basal $(\mathrm{O})$ and $\mathrm{GnRH}$-stimulated ( $)$ FSH secretion, and (b) basal $(\mathrm{O})$ and GnRH-stimulated (-) $\mathrm{LH}$ secretion. Basal secretion was measured over $48 \mathrm{~h}$ followed by $4 \mathrm{~h}$ stimulation with $10^{-8} \mathrm{~mol} \mathrm{GnRH}$ $1^{-1}$. The $\mathrm{ED}_{50}$ value for basal FSH was $0.8 \mathrm{ng}$ inhibin $\mathrm{ml}^{-1}$, for $\mathrm{GnRH}$-stimulated FSH, $3.9 \mathrm{ng}$ inhibin $\mathrm{ml}^{-1}$. The $\mathrm{ED}_{50}$ value was not achieved for either basal or GnRH-stimulated $\mathrm{LH}$ secretion and the $\mathrm{ED}_{25}$ value for the latter was $4.5 \mathrm{ng} \mathrm{ml}^{-1}$.

$\left(1.25 \mathrm{ng} \mathrm{ml}^{-1}, P=0.04 ; 2.5 \mathrm{ng} \mathrm{ml}^{-1}, P=0.0004\right.$, compared with control). However, there was a significant effect of the anti-inhibin antibody on all doses of human inhibin $(0.313 \mathrm{ng}$ $\mathrm{ml}^{-1}, P=0.0001 ; 0.625 \mathrm{ng} \mathrm{ml}^{-1}, P<0.0001 ; 1.25 \mathrm{ng} \mathrm{ml}^{-1}$, $P=0.002$ and $\left.2.5 \mathrm{ng} \mathrm{ml}^{-1}, P<0.0001\right)$ and the pig inhibin $(P<0.0001)$. With respect to GnRH-stimulated FSH secretion, the preparation was more sensitive to lower doses of inhibin (data not presented) and maximal suppression was achieved with $0.3 \mathrm{ng} \mathrm{ml}^{-1}$; the anti-inhibin antibody affected all doses of inhibin. The four doses of human inhibin $(0.313,0.625,1.25$ and $2.5 \mathrm{ng} \mathrm{ml}^{-1}$ ) inhibited GnRH-stimulated FSH secretion by $51.0 \%, 51.6 \%, 47.8 \%$ and $50.3 \%$, respectively, and the single dose of pig inhibin achieved $52.2 \%$ inhibition. There was a significant effect of the anti-inhibin antibody on all doses of 



Fig. 3. The effect of recombinantly derived human inhibin, pig inhibin and gonadotrophin surge inhibiting factor (GnSIF) on (a) basal and (b) GnRH-stimulated FSH secretion and (c) basal and (d) GnRH-stimulated LH secretion. Pig inhibin was used as a control as the GnSIF was derived from pig follicular fluid. The samples were added untreated $(L)$ and after treatment with an anti-inhibin antibody ( $\mathbf{-}){ }^{*}$ Significantly different from control; ${ }^{\dagger}$ significant inhibition of inhibin effect by anti-inhibin antibody.

human inhibin $10.313 \mathrm{ng} \mathrm{ml}^{-1}, P=0.001 ; 0.625 \mathrm{ng} \mathrm{ml}^{-1}$, $P=0.0003 ; \quad 1.25 \mathrm{ng} \mathrm{ml}^{-1}, P=0.0003$ and $2.5 \mathrm{ng} \mathrm{ml}^{-1}$, $P=0.0008)$ and on the pig inhibin $(P=0.014)$. Basal $L H$ secretion was suppressed by pig inhibin but not by human inhibin (Fig. 3). Treatment with anti-inhibin antibody reversed the effect of pig inhibin and caused a slight stimulation at some doses, possibly owing to a nonspecific protein effect. GnRHstimulated LH secretion was inhibited by both the pig inhibin (17.1\% inhibition) and the highest two doses of human inhibin (1.25 $\mathrm{ng} \mathrm{ml}^{-1}, 23.2 \%$ and $2.5 \mathrm{ng} \mathrm{ml}^{-1}, 35.1 \%$ inhibition) and these effects were lost after treatment with anti-inhibin antibody (pig inhibin, $P=0.014$; human inhibin $1.25 \mathrm{ng} \mathrm{ml}^{-1}$ and $\left.2.5 \mathrm{ng} \mathrm{ml}^{-1}, P<0.0005\right)$.

The GnSIF preparation inhibited basal FSH $\left(8 \mu \mathrm{g} \mathrm{m}{ }^{-1}\right.$, $P=0.0003 ; 4 \mu \mathrm{g} \mathrm{ml}^{-1}, P=0.003 ; 2 \mu \mathrm{g} \mathrm{ml}^{-1}, P=0.015 \mathrm{com}-$ pared with control) with an $\mathrm{ED}_{50}$ value of $8 \mu \mathrm{g} \mathrm{ml}^{-1}$. These effects of GnSIF were not affected by the anti-inhibin. Only the highest dose of GnSIF ( $\left.8 \mu \mathrm{g} \mathrm{ml}^{-1}\right)$ inhibited GnRH-stimulated FSH secretion $(P=0.003)$ and the $\mathrm{ED}_{50}$ value was $7 \mu \mathrm{g} \mathrm{ml}^{-1}$. GnSIF had no significant effect on basal LH secretion but significantly inhibited GnRH-stimulated $\mathrm{LH}$ secretion at $4 \mu \mathrm{g}$ $\mathrm{ml}^{-1}$ and $8 \mu \mathrm{g} \mathrm{ml}^{-1}(P=0.0033$ and $P=0.00047$, respectively). The anti-inhibin antibody did not remove the inhibitory effects of GnSIF in these experiments.

\section{Discussion}

An anti-inhibin antibody was used to determine the differential effects of inhibin and a partially purified preparation of GnSIF on gonadotrophin secretion by a rat pituicyte bioassay.
Because the GnSIF was purified from pig follicular fluid and an anti-human inhibin antibody was used, both pig and human inhibin were used in the bioassay. There is considerable cross-species conservation of the inhibin molecule and both pig and human inhibin have biological effects on the secretion of FSH by rat pituitary cells (Gaines Das et al., 1992; Rivier et al., 1991). The First International Standard preparation for pig inhibin (NIBSC 86/690) was used in some of the experiments and in others an NIBSC-ampouled preparation of recombinant DNA derived human inhibin was used.

In rats treated with $\mathrm{FSH}$, the preovulatory gonadotrophin surge of FSH and LH is inhibited; this effect is reversed by the administration of an anti-inhibin antibody (Culler, 1992). However, the same anti-inhibin antibody does not affect GnSAF bioactivity in human serum and follicular fluid (Byrne et al, 1995; Fowler et al., 1995). Furthermore, the purified preparation of GnSIF from a Sertoli cell culture (Tio et al., 1994) inhibits both GnRH-stimulated LH and basal FSH release.

In the study reported here the highly purified preparation of GnSIF had a dose-dependent inhibitory effect on GnRHstimulated FSH and $\mathrm{LH}$ secretion. In addition, there was an inhibitory effect on basal FSH secretion, in the absence of any signs of toxicity. The inhibition of basal FSH is contrary to the findings of other workers (D. R. Danforth, personal communication); this may be due to different bioassay and experimental designs. Although the original hypothesis was that the effects of GnSIF are on GnRH-stimulated gonadotrophin secretion, others have occasionally observed such an inhibitory effect on basal FSH secretion (Tio et al., 1994, P. Fowler, personal communication). A possible explanation is that other inhibitors of basal FSH secretion, such as follistatin, 
are present in the partially purified preparations that have been used, although none was detected in the GnSIF that was added in the above experiments (D. R. Danforth, personal communication).

The precise actions of GnSAF/GnSIF will not be known until the protein is completely purified and its properties examined thoroughly. It seems reasonable to postulate that inhibin and other non-steroidal hormones have effects at different stages of the oestrous cycle and at different serum concentrations, and are involved in the fine-tuning of pituitary secretion of gonadotrophins.

Anti-human inhibin antibody immunoneutralized the effects of both human and pig inhibin. There is considerable similarity between the structure of the $\alpha$ - and $\beta$-chain within and between species (Forage et al., 1987). The sequences of the $\alpha$-chain show $85 \%$ similarity between cattle, humans and pigs. Even greater conservation is seen with the $\beta_{\mathrm{A}}$-subunit; there is a single amino acid difference in sheep molecules from those of cattle, pigs, rats and humans (Forage et al., 1987). Where it is present, the $\beta_{B}$-subunit shows over $85 \%$ conservation of structure. Therefore, it is not surprising that the anti-human inhibin antibody recognizes pig inhibin. The observation that the anti-inhibin antibody did not inhibit the bioactivity of GnSIF demonstrates that the putative pig GnSIF is different from inhibin and confirms the observations of Byrne et al. (1995) and Fowler et al. (1995). In the study reported here a preparation of almost completely purified GnSIF was added to the bioassay, and FSH and LH secretion were inhibited. The effects of GnSIF were not inhibited by the anti-inhibin antibody, demonstrating that pig GnSIF is different from inhibin.

The authors thank D. R. Danforth, Department of Obstetrics and Gynecology, Ohio State University, Columbus, $\mathrm{OH}$, for his generous gift of the preparation of GnSIF. They also thank A. McNeilly, Reproductive Biology Unit, Edinburgh for the kind gift of anti-inhibin antibody. This research was funded largely by grants from the North East Thames Regional Health Authority Locally Organized Research Scheme and the Middlesex Hospital Special Trustees. The authors are also grateful to The Robert Malcolm Trust for financial support and to H. Jacobs, Middlesex Hospital, London and S. Jeffcoate, NIBSC, for advice on experimental methodology.

\section{References}

Balen AH and Jacobs HS (1991) Gonadotrophin surge attenuating factor: a missing link in the control of LH secretion? Clinical Endocrinology $\mathbf{3 5}$ $399-402$

Balen AH, Er J, Rafferty B and Rose M (1995) Characterisation of a rat anterior pituitary cell bioassay In Vitro Cellular and Developmental Biology 31 316-322

Burger HG (1992) Inhibin: review Reproductive Medicine Reviews 1 1-20

Byrne B, Fowler PA, Fraser M, Culler MD and Templeton AA (1995) GnSAF bioactivity in serum from superovulated women is not blocked by inhibin antibody Biology of Reproduction $5288-95$

Culler MD (1992) In vivo evidence that inhibin is a gonadotrophin surge inhibiting/attenuating factor Endocrinology 131 1556-1558

Danforth DR and Cheng CX (1993) The identification of gonadotropin surge inhibiting factor (GnSIF) and its role in the regulation of gonadotropin secretion Human Reproduction 8 (Supplement 2) 117-122

Danforth DR, Sinosich MJ, Anderson TL, Cheng CY, Bardin CW and Hodgen GD (1987) Identification of gonadotrophin surge inhibiting factor in follicular fluid and its differentiation from inhibin Biology of Reproduction 37 10751082

Forage RG, Brown RW, Ring JM, Stewart AG, Milborrow HM, Oliver KJ, Atrache BT, Devine PL, Hudson GC, Goss NH, Tolstoshev P, Robertson DM, Doughton B, de Kretser DM, Burger HG and Findlay JK (1987) The cloning and expression of inhibin genes: subunit use as a fecundity vaccine. In Inhibin Non-steroidal Regulation of Follicle Stimulating Hormone Secretion Eds HG Burger, DM de Kretser, JK Findlay and M Igarashi Serono Symposia 42 89-103

Fowler PA, Messinis IE and Templeton AA (1990) Inhibition of LHRH-induced $\mathrm{LH}$ and FSH release by gonadotrophin surge attenuating factor from human follicular fluid Journal of Reproduction and Fertility 90 587-594

Fowler PA, Fahy U, Culler MD, Knight PG, Wardle PG, McLaughlin EA, Cunningham P, Fraser M, Hull MGR and Templeton A (1995) Gonadotrophin surge-attenuating factor bioactivity is present in follicular fluid from naturally cycling women Human Reproduction 10 68-74

Gaines Das RE, Rose M and Zanelli JM (1992) International collaborative study by in vitro bioassays of the first International Standard for porcine inhibin Journal of Reproduction and Fertility 96 803-814

Messinis IE and Templeton A (1989) Pituitary response to exogenous LHRH in superovulated women Journal of Reproduction and Fertility 87 633-639

Rivier C, Schwall R, Mason A, Burton L, Vaughan J and Vale W (1991) Effect of recombinant inhibin on LH and FSH secretion in the rat Endocrinology 128 1548-1554

Sopelak VM and Hodgen GD (1984) Blockade of the estrogen-induced luteinising hormone surge in monkeys: a nonsteroidal, antigenic factor in porcine follicular fluid Fertility and Sterility 41 108-113

Tio S, Koppenaal D, Bardin CW and Cheng CY (1994) Purification of gonadotropin surge-inhibiting factor from Sertoli cell-enriched culture medium Biochemical and Biophysical Research Communications 199 1229-1236 